\title{
EFL Students' Perceptions of Social Presence and Satisfaction in Online Learning
}

\author{
Tara Sania Suryana Putri ${ }^{1 *}$,Nanik Mariani ${ }^{2}$ Fatchul Mu'in ${ }^{3}$ \\ ${ }^{1,2,3}$ Lambung Mangkurat University \\ *Corresponding author. Email: $1710117220037 @$ mhs.ulm.ac.id
}

\begin{abstract}
Research shows online students are more likely to quit class if they do not like the instructor, the format, or the feedback. In addition, since they work independently, relying almost wholly upon self-motivation and self-direction, online learners may be more inclined to withdraw from the class if they do not get immediate results. In Indonesia, online learning is spot as deficient compared with face-to-face learning. It is notably due to the lack of social presence and lacks' of students satisfaction. However, little research has been done to investigate students' perception of online learning in Junior High School. This study describes students' perceptions of social presence and satisfaction by 9th grade at SMPN 3 Banjarmasin. The researcher conducted a qualitative approach with the descriptive method. The total number of respondents is 54 students. The researcher used online instruments which questionnaire and interview for collecting the data. The result in this study indicated that most students felt comfortable introducing themselves and communicating in an online environment. Furthermore, students are satisfied knowing that they can deepen the subject matter at home. Besides, students are not satisfied that they can understand the subject well in online learning. The finding was also found that student's willingness to take more online classes is strongly disagreed.
\end{abstract}

Keywords: Online Learning, Social Presence, Students Satisfaction.

\section{INTRODUCTION}

Due to the Covid-19 pandemic, the provincial and local governments of Indonesia produced policies in the area of education by temporarily eliminating face-toface learning and replacing it with online learning at both school and college levels, manifested in a system called electronic learning (e-Learning) [1]. On April 19, 2020, the Ministry of Health approved Pembatasan Sosial Berskala Besar (PSBB), which impacted learning activities in schools and universities.

Students do not have to attend class with online learning methods. Students can just use the internet to access information. If technology is balanced with interaction and education, it can be used to improve higher-order thinking skills [2]. This technological advance makes it easier to use the internet to access learning resources, interact with content, instructors, and other students, find support, obtain information, construct personal meaning, and grow from the learning experience. In general, each teacher can choose the optimal learning technique for their students. Online learning is safer than face-to-face learning because it lessens the physical impact of bullying and allows students to bravely share their thoughts, concerns, or answers online without fear of unwanted replies from others [3].

In Indonesia, online learning is spotted as deficient compared with face-to-face learning. It is notably due to the lack of social presence and lacks' of students satisfaction. Social Presence is a concept with the quality of communications medium that determines how students interact, and Students Satisfaction is a shortterm attitude resulting from evaluating students' educational experience, services, and facilities. According to studies, online students who dislike the instructor, the structure, or the feedback are more likely to drop out. Furthermore, because they work individually and rely almost entirely on self-motivation and self-direction, online students may be more likely to drop out of class if they do not see rapid results. 
However, little research has been done to investigate students' perception of online learning in Junior High School, in which understanding the students' needs is also required. Students at this age reached emotional instability, a feeling of emptiness due to changes in views and life clue, an attitude of resistance, conflict within him is often the root cause of conflicts with parents, anxiety because many things are wanted [4]. Still, teenagers cannot fulfill all of the glad experimenting, happy exploring, a lot of fantasy, delusion, and gibberish. Since then, it is essential to examine students' perceptions of online learning particularly in SMP 3 Banjarmasin to reveal whether it affects their social presence and satisfaction. Hence, the research question is formulated into "What are students' perceptions of social presence and students' satisfaction in online learning by 9th-grade students at SMPN 3 Banjarmasin?"

\section{LITERATURE REVIEW}

\subsection{Online Learning}

Through a computer-based learning system, the University of Illinois pioneered electronic-based learning (e-learning), which inspired the development of online learning. Students can learn more generally, more comprehensively, and in a more diverse manner through online learning. The system's characteristics enable students to learn whenever and wherever they need, regardless of distance, location, or time. Students' accuracy and insight are emphasized in online learning as they receive and process information. Students and teachers engage using computer media connected to the internet, phone, or fax in online learning.

The impact of online learning in Indonesia is starting to emerge, beginning with the independent learning process and the activities assigned. Independent learning emphasizes learning from a variety of sources with little or no help from others. At first, online education was still combined with conventional education to train students to be more independent. Practicing independent learning for students in Indonesia is not easy because the previous learning system (traditional pattern) assumed that the teacher was the primary source of education. After students are more independent, then they can do online learning thoroughly. When there was distance learning, the evolution of online learning became apparent. Through distance learning, the government can solve the problem of equal distribution of education for all individuals. Through distance learning, the learning process is combined with e-learning; since then, online learning has continued to develop in Indonesia. Online learning is increasingly being used today, and maybe we can assume that this teaching-learning is suitable and has a myriad of advantages. However, if this media is not designed correctly, instead of the benefits obtained, boredom arises.

\subsection{Social Presence}

Social presence is a concept with the quality of communications medium that determines how students interact or "the degree to which a person viewed as "real" in mediated conversation [5]. Online education is criticized because it lack of social cues and thus would interfere the teaching and learning [6]. In contrast, the lack of social presence can lead to more frustration and less affective learning [7]. However, online education keeps growing as access to the Internet and students' enrollment increase every year [8].

\subsection{Students Satisfaction}

Students' satisfaction can be described as a straightforward attitude originating from assessing the educational experience, services, and facilities provided to students [20] , [21]. Many researchers have used many methods to analyze this to define and assess students' satisfaction, essentially students' final grades, self-reports of satisfaction, attitudes within an online class, and course completion rates [9]. Another characteristic that has been highlighted as related to increased student satisfaction in online education is the social presence [10]. Student happiness is a combination of responsive, accessible, individualized services and support, high-quality learning outcomes, academic and administrative support services, and learner interaction and cooperation [11]. In online courses, support services have also been identified as a predictor of student satisfaction [12]. In addition, course flexibility, social presence, technical support, and course technology, all influence student satisfaction [13].

\section{METHOD}

This research applied a descriptive research with mixed-methods. A questionnaire and interview were used to collect the data in the research. The researchers determined two classes as the sample. There were 56 students chosen as the participants. The questionnaire was adapted and translated from similar previous studies. The questionnaire consists of 20 closed-ended statements (each scale has ten statements) using a fiveLikert scale. The questionnaire was administered to figure out students' perception of social presence and satisfaction in online learning. Meanwhile, the interview was conducted with four students. The interview consists of eight questions aimed to gain in-depth explanation and description of students' experiences. All students' data remained anonymous.

The percentage of each statement was calculated statistically using the data from the students' closedended questionnaire and then descriptively evaluated. 
The interview transcripts were all transcribed and reviewed for common themes linked to the students' perceptions of online learning. The repetition of a particular viewpoint can be interpreted as the participants' care about the problem. The information gathered from the questionnaire and interview was utilized to describe students' perceptions of social presence and satisfaction after one year of online learning at home.

\section{RESULT AND DISCUSSION}

The students have experienced online courses for at least one year. To answer research questions, the findings from the students' questionnaire are shown in the tables.

Table 1 shows that most students agreed (54\%) that they are comfortable enough to introduce themselves in online classes. The students also thought they were comfortable enough to participate in discussions in online classes with $46 \%$ agreed. However, there are students who are neutral (43\%) and disagree (19\%). It can be concluded that some students felt comfortable when they speak in online classes and some others were not. In the interview, the students stated that they tended to wait for their peers to voice in online courses because they think there will be repeated questions.

The table also showed that students in an online class could acknowledge their opinion with 50\% choosing agree. Although the data from the previous question showed that many students felt neutral speaking in online courses, the result of statement 5 showed that many students (strongly agree is $19 \%$ and agree is 48\%) still prefer communication in online classes that are not impersonal. They felt safe for online learning because they are not laughed by their classmates when they mispronounce some word.

Table 1. Students' Perceptions of Social Presence in Online Learning

\begin{tabular}{|c|c|c|c|c|c|}
\hline Statements & $\begin{array}{l}\text { Strongly } \\
\text { Agree }\end{array}$ & Agree & Neutral & Disagree & $\begin{array}{l}\text { Strongly } \\
\text { Disagree }\end{array}$ \\
\hline $\begin{array}{l}\text { 1. Saya merasa nyaman memperkenalkan } \\
\text { diri di kelas online. }\end{array}$ & $13 \%$ & $54 \%$ & $26 \%$ & $7 \%$ & $0 \%$ \\
\hline $\begin{array}{l}\text { 2. Saya merasa nyaman berpartisipasi dalam } \\
\text { diskusi di kelas online }\end{array}$ & $11 \%$ & $46 \%$ & $30 \%$ & $13 \%$ & $0 \%$ \\
\hline $\begin{array}{l}\text { 3. Saya merasa nyaman berbicara di dalam } \\
\text { kelas online. }\end{array}$ & $7 \%$ & $31 \%$ & $43 \%$ & $19 \%$ & $0 \%$ \\
\hline $\begin{array}{l}\text { 4. Saya merasa opini (pendapat) saya } \\
\text { diterima oleh siswa lain di dalam kelas } \\
\text { online }\end{array}$ & $6 \%$ & $50 \%$ & $39 \%$ & $6 \%$ & $0 \%$ \\
\hline $\begin{array}{l}\text { 5. Saya suka berkomunikasi di dalam kelas } \\
\text { online karena tidak bersifat pribadi } \\
\text { (impersonal) seperti bullying, body shame } \\
\text { maupun kritikan terhadap diri saya }\end{array}$ & $19 \%$ & $48 \%$ & $19 \%$ & $15 \%$ & $0 \%$ \\
\hline
\end{tabular}


Table 2. Students' Perceptions of Social Presence in Online Learning

\begin{tabular}{l|c|c|c|c|c}
\hline Statements & $\begin{array}{l}\text { Strongly } \\
\text { Agree }\end{array}$ & Agree & Neutral & Disagree & $\begin{array}{c}\text { Strongly } \\
\text { Disagree }\end{array}$ \\
\hline $\begin{array}{l}\text { 6. Salam pembuka di kelas online } \\
\text { memungkinkan saya membentuk rasa } \\
\text { komunitas online }\end{array}$ & $13 \%$ & $44 \%$ & $35 \%$ & $7 \%$ & $0 \%$ \\
\hline $\begin{array}{l}\text { Meskipun kami tidak bersama secara fisik } \\
\text { di ruang kelas tatap muka, saya masih } \\
\text { merasa seperti menjadi bagian dari } \\
\text { kelompok dalam kelas online }\end{array}$ & $28 \%$ & $52 \%$ & $17 \%$ & $8 \%$ & $0 \%$ \\
\hline $\begin{array}{l}\text { Pembelajaran online adalah pembelajaran } \\
\text { yang baik untuk berinteraksi dengan } \\
\text { teman-teman }\end{array}$ & $15 \%$ & $17 \%$ & $22 \%$ & $37 \%$ & $9 \%$ \\
\hline $\begin{array}{l}\text { Diskusi di dalam kelas online bersifat } \\
\text { pribadi (impersonal) daripada kelas tatap } \\
\text { muka }\end{array}$ & $9 \%$ & $46 \%$ & $35 \%$ & $9 \%$ & $0 \%$ \\
\hline $\begin{array}{l}\text { 10. Guru memfasilitasi pembelajaran online } \\
\text { seperti membuka sesi tanya-jawab di } \\
\text { WhatsApp Grup }\end{array}$ & $28 \%$ & $52 \%$ & $17 \%$ & $4 \%$ & $0 \%$ \\
\hline
\end{tabular}

Table 2 shows that half of the students agreed that the introductions created by the teacher in online classes can form a sense of online community. It is also followed by statement 7 that students still felt the sense of group works just like the face-to-face learning. This indicated that the interactions between students in faceto-face learning is still happening in online classes. Although previous data showed that students still could feel the sense of group works, in statement 8 , students are not feeling comfortable interacting with friends in online learning (disagree $=37 \%$ ). In the interview section or in-depth explanation, students stated that they could interact with their friends in face-to-face education. Yet, their interaction is limited in online learning.

They also did not feel the class as they could not feel the atmosphere of real classroom. Furthermore, discussions in online learning tend to be personal (agree $=46 \%$ ). It can be virtual bullying, critiques of their personality, or something that they do not want to hear. However, half of the students $(\mathrm{SA}=28 \%$, agree $=52 \%)$ agreed that they are satisfied with the teacher by opened Question and Answer in WhatsApp Group, which is one of the student needs. Thus, the facts above suggest that students' satisfaction with their instructor is good enough for students and satisfying.

Table 3. Students' Perceptions of Satisfaction in Online Learning

\begin{tabular}{c|c|c|c|c|c}
\hline Statements & $\begin{array}{l}\text { Strongly } \\
\text { Agree }\end{array}$ & Agree & Neutral & Disagree & $\begin{array}{c}\text { Strongly } \\
\text { Disagree }\end{array}$ \\
\hline $\begin{array}{c}\text { 11. Saya mendapatkan kesempatan lebih } \\
\text { untuk dapat mengulang apa yang telah } \\
\text { saya pelajari dalam pembelajaran online di } \\
\text { rumah }\end{array}$ & $13 \%$ & $54 \%$ & $26 \%$ & $7 \%$ & $0 \%$ \\
\hline $\begin{array}{c}\text { 12. Pembelajaran online membantu saya } \\
\text { memahami materi pelajaran }\end{array}$ & $11 \%$ & $46 \%$ & $30 \%$ & $13 \%$ & $0 \%$ \\
\hline $\begin{array}{c}\text { 13. Saya merasa mendapatkan kesempatan } \\
\text { yang besar untuk dapat bekerjasama } \\
\text { dengan siswa lain di dalam pembelajaran } \\
\text { online ini }\end{array}$ & $7 \%$ & $31 \%$ & $43 \%$ & $19 \%$ & $0 \%$ \\
\hline
\end{tabular}


However, when tasks came, they did it right away. They think they have 24 hours, and they can finish it anytime.

\begin{tabular}{c|c|c|c|c|c}
\hline Statements & $\begin{array}{l}\text { Strongly } \\
\text { Agree }\end{array}$ & Agree & Neutral & Disagree & $\begin{array}{c}\text { Strongly } \\
\text { Disagree }\end{array}$ \\
\hline $\begin{array}{c}\text { 14. Pengalaman saya dalam pembelajaran } \\
\text { online adalah saya dapat meningkatkan } \\
\text { kesempatan saya dalam mengakses dan } \\
\text { mencari informasi }\end{array}$ & $6 \%$ & $50 \%$ & $39 \%$ & $6 \%$ & $0 \%$ \\
\hline $\begin{array}{c}\text { 15. Saya merasa lebih berani/ nyaman untuk } \\
\text { mengajukan pertanyaan dalam kelas } \\
\text { online }\end{array}$ & $11 \%$ & $30 \%$ & $37 \%$ & $17 \%$ & $6 \%$ \\
\hline
\end{tabular}

Table 3 shows that most students $(\mathrm{SA}=33 \%$, agree $=$ $50 \%$ ) agreed that online learning allows them to deepen the lesson. However, although they could deepen the lesson, students feel online learning cannot help them understand the material (disagree $=41 \%$ ). In-depth explanation, they stated that it complicates them for most teachers only shared PPTs on WhatsApp without enough explanation. Besides, students also felt that they had a big opportunity in online classes by working together with their friends (agree $=37 \%$ ) as it could help them to comprehend the lesson materials.

Table 4. Students' Perceptions of Satisfaction in Online Learning

\begin{tabular}{|c|c|c|c|c|c|}
\hline Statements & $\begin{array}{l}\text { Strongly } \\
\text { Agree }\end{array}$ & Agree & Neutral & Disagree & $\begin{array}{l}\text { Strongly } \\
\text { Disagree }\end{array}$ \\
\hline $\begin{array}{l}\text { 16. Secara umum, saya lebih mengerti } \\
\text { persyaratan kenaikan kelas lebih baik } \\
\text { pada pembelajaran online }\end{array}$ & $6 \%$ & $26 \%$ & $43 \%$ & $22 \%$ & $4 \%$ \\
\hline $\begin{array}{l}\text { 17. Saya dapat mengatur jadwal belajar saya } \\
\text { lebih baik pada kelas online }\end{array}$ & $19 \%$ & $26 \%$ & $28 \%$ & $19 \%$ & $5 \%$ \\
\hline $\begin{array}{l}\text { 18. Nilai akademik saya sekarang (kelas } \\
\text { online) lebih baik dari sebelumnya (kelas } \\
\text { tatap muka) }\end{array}$ & $20 \%$ & $13 \%$ & $37 \%$ & $22 \%$ & $7 \%$ \\
\hline $\begin{array}{l}\text { 19. Saya lebih mudah memonitor (memantau) } \\
\text { nilai akademik saya dalam pembelajaran } \\
\text { online ini }\end{array}$ & $17 \%$ & $46 \%$ & $17 \%$ & $19 \%$ & $2 \%$ \\
\hline $\begin{array}{l}\text { 20. Saya ingin mengambil kelas online lagi jika } \\
\text { ada (impersonal) seperti bullying, body } \\
\text { shame maupun kritikan terhadap diri saya }\end{array}$ & $7 \%$ & $15 \%$ & $26 \%$ & $22 \%$ & $30 \%$ \\
\hline
\end{tabular}

Table 4 shows that half of the students cannot decide whether or not they understand class requirements in an online class better than in face-to-face learning $(43 \%$ students chose neutral). Yet, $26 \%$ students chose agree to this statement. Since online learning required students to be independent, statement 17 shows that the phenomenon regarding students' time management is stable (neutral $=28 \%$ ). In the interview section, they said that they had the class schedules and understood it.
In addition, online learning helped them increase their opportunity in searching for what they need from the internet. Most students respond neutral for statement 15 ; this indicates that students are still not sure they feel comfortable asking questions in the online class. Thus, the facts above suggest that the phenomenon regarding students' comfort in asking questions is stable. However, the interview result revealed that the teacher's response to their questions was slow. Therefore, they prefer to ask their closest friends or browse in the Internet. This result is similar to the statement by Sutton 
[22] that students learn almost as much from vicarious interaction.

Same as previous data, students' academic scores are also stable $(37 \%)$; they stated that their academic scores were similar to face-to-face learning, neither increasing nor decreasing. They can access their tasks via the internet, while in face-to-face learning, their access was limited. Besides, they can monitor their grades easily (46\%). After all, it still did not make them want to take online classes (30\% students chose disagree); they want to interact with their friends at school directly to feel "the real" interaction. In the interview result, they mentioned that online learning is different from face-toface learning. Even though it is easy for them to access information, their interaction in online classes is limited.

Based on the results, most of the students have a good impression of communicating in online classes. It is contrary to [16], saying that online courses feel comfortable relating and interacting in the online environment. This may be due to differences in the subjects' characteristics. However, the gap could also be linked to changing attitudes during online class and social presence over time. In face-to-face learning, students can meet directly, have eye contact, and others physical activities that could reduce psychological distance between peers and lead to significant interaction while online learning did not have it all. Moreover, from 8 to 10 statements in the questionnaire, most students agreed that they felt comfortable communicating in online learning. In line with a study by Cobb [17], resulting in no subject expressed any level of disagreement with the items and all respondents felt comfortable introducing themselves and communicating in an online environment.

Furthermore, students are satisfied knowing that they can deepen the subject matter at home. As stated by McGorry [18], students' happiness is influenced by course flexibility. However, students are not satisfied on the statement that they can understand the subject well in online learning (item 12). They stated that teachers do not explain the materials given neither make any conference. It is also in line with the research by Eom, Wen and Ashill [19] saying that online learning may block students' learning progress. According to their findings, teachers should carefully assess students' expectations and skills before integrating online activities, readings, resources, and work contributions.

Additionally, the students themselves determine the completeness of learning and understanding of the material in online education. Students are required to be independent and find their knowledge. The success of each student will vary, depending on how independent the student is. The four highest-scoring items $(11,13,14$ and 19) concerned the opportunity to deepen the lesson. All respondents felt satisfied knowing that they had the chance to deepen the lesson freely anytime and they also can monitor their score directly. There was no respondent indicated any level of disagreement with any of these items. The lowest score was on the item 20 that was about students' willingness to take online classes. The students admitted that when the teaching and learning process occurs, there is no direct interaction between students and teachers. This leads to students' disapproval to take online classes and thus demotivated them in learning. As it is stated by Eom, Wen and Ashill [19], students' satisfaction would be related to student self-motivation.

Since all of the subject-students in this study are students at SMPN 3 Banjarmasin who have experienced face-to-face learning for two years and one year online, they believe that online learning has had a significant impact for some reasons. They felt comfortable introducing themselves and communicating online, yet they did not get direct interactions among them. This made them refuse online classes; they preferred to have traditional face-to-face classroom.

\section{CONCLUSION}

Based on the findings, it can be concluded that students felt comfortable communicating in online learning; in contrast, students are unsure if they are satisfied or not with online learning. This indicates that online learning has its positive and negative values. Students also mentioned that it is easier to find knowledge in the internet and that online classes also make them easy to keep track of their grades. These are the positive values of online courses. They acknowledged the negative side of online learning is that they could not comprehend the subject well since they did not meet the teachers face-to-face like they were used to be. These findings imply the need of teachers' attention to what benefits online learning brings and what makes students like or dislike learning in online classroom.

\section{AUTHORS' CONTRIBUTIONS}

Author 1 contributed to research design, collect the data, and data analysis. Author 2 is responsible for the data analysis and writing the report whereas Author 3 contributed to writing format.

\section{ACKNOWLEDGMENTS}

The researchers are very grateful to the experts for validating the research instrument and the subjects of the research for participating in the study.

\section{REFERENCES}

[1] Z. Zhafira, N. Hilmy, Y. Ertika, C. Chairiyaton. Persepsi Mahasiswa terhadap Perkuliahan Daring 
Sebagai Sarana Pembelajaran Selama Masa Karantina Covid-19, in: Proceedings of Jurnal Bisnis dan Kajian Strategi Manajemen vol. 4, no. 1, 2020, pp. 37 - 45. ISSN: 2614-2147.

[2] Y. G. Lashley, Integrating computer technology in the teaching of Biology, inL Proceedings of International Journal Of Biology Education, vol. 3, 2014

[3] A. N, Sobron, B. Bayu, R. Rani, S. Meidawati , Persepsi Siswa dalam Studi Pengaruh Daring Learning terhadap Minat Belajar IPA. In: Proceedings of SCAFFOLDING: Jurnal Pendidikan Islam dan Multikulturalisme, vol. 1, No. 2, 2019, pp. $30-38$.

[4] G.Gunarsa. Permasalahan Perkembangan Fisik. In Dr. Masganti Sit, M.Ag (Eds.), Proceedings of Perkembangan Peserta Didik, 1989, p. 75. ISBN 978-602-8935-11-1. 1989

[5] C.N. Gunawardena, F.J. Zittle, Social Presence as a Predictor of Satisfaction Within a Computer Mediated Conferencing Environment. The American Journal of Distance Education, vol. 11, 1997, pp.8-26

[6] Z. Berge, M. Collins, Computer-mediated communication and the Online Classroom in Distance Learning, in: Computer-Mediated Communication, vol. 2, no. 4, 1995, p.6, retrieved from

https://www.december.com/cmc/mag/1995/apr/ber ge.html

[7] L. J. Rifkind, Immediacy as a predictor of teacher effectiveness in the instructional television. Journal of Interactive Television, vol. 1(1), 1992, pp. 3138 .

[8] I. E. Allen, J. Seaman, Making the grade: Online education in the United States, Needham, MA: Sloan-C, 2006

[9] J. G. Seiver, A. Troja, Satisfaction and Success In Online Learning As a Function of The Needs for Affiliation, Autonomy, and Mastery, in: Proceedings of Distance Education, vol. 35, issue. 1, 2014, p. 90-105.

[10] J. C. Richardson, K. Swan, Examining social presence in online courses in relation to students' perceived learning and satisfaction, in: Proceedings of Journal of Asynchronous Learning Networks, vol. 7 no. 1,2003 , p.68-88.

[11] G. Lorenzo, J. Moore, Five pillars of quality online education. Retrieved from The Sloan Consortium Report to the Nation: http://sloanconsortium.org/ November 2002
[12] O. Halic, D. Lee, T. Paulus, M. Spence, To blog or not to blog: Student perceptions of blog effectiveness for learning in a college-level course. Internet and Higher Education, vol. 13, 2010, pp. 206-213

[13] S. Y. McGorry, Measuring quality in online programs, in : Proceedings of Internet and Higher Education(6), 2003, p. 159-177.

[14] C.N. Gunawardena and F.J. Zittle, Social Presence as a Predictor of Satisfaction Within a Computer Mediated Conferencing Environment, in: Proceedings of The American Journal of Distance Education, vol. 11, 1997, pp.8-26

[15] D. Dziuban et al., Student Satisfaction with Online Learning: Is it a Psychological Contract?, in: Proceedings of The Official Journal of OLC, 2015. DOI: http://dx.doi.org/10.24059/olj.v19i2.496

[16] D. J. Skiba, N. K. Holloway, H. Springer, H. Measurement of best practices and social presence in web-based international nursing informatics pilot course. Nursing Informatics, in: Proceedings of the 7th IMIA International Conference on Nursing, 2000, pp.650-657

[17] S. C. Cobb, Social Presence and Online Learning: A Current View from a Research Perspective, in: Proceedings of Journal of Interactive Online Learning, vol.8, no.3, 2009. ISSN: 1541-4914

[18] S. Y. McGorry, Measuring quality in online programs. Internet and Higher Education, vol. 6, 2003, pp. 159-177.

[19] Eom, S. B., Wen, H. J., \& Ashill, N. The determinants of students' perceived learning outcomes and satisfaction in online university education: An empirical investigation, in: Proccedings of Decision Sciences Journal of Innovative Education, vol. 4, no. 2, 2006, pp.215235

[20] K. M. Elliott and M. A. Healy, Key factors influencing student satisfaction related to recruitment and retention, in: Proceedings of Journal of Marketing for Higher Education, vol. 10, no. 4, 2001, pp. 1-11.

[21] S. Weerasinghe R. L. Fernando, Students' satisfaction in higher education, in: Proceedings of American Journal of Educational Research, vol. 5, no. 5, 2017, pp. 533-539.

[22] L. Sutton, Leah, The Principle of Vicarious Interaction in Computer-Mediated Communications. In: Proccedings of International Journal of Educational Telecommunications, vol. 7. 2001. 